\title{
Die Vraagstuk van Misleiding, Verrassing en Vertolking van Informasie in Oorlog, met Spesifieke Verwysing na die rol wat dit in Egipte se Aanval op Israel op 6 Oktober 1973 gespeel het
}

\author{
A.J. ESTERHUYSE \\ Dosent, Departement Militêre Strategie, Fakulteit Krygskunde, \\ Universiteit Stellenbosch
}

\begin{abstract}
The Question of Deception, Surprise and Interpretation of Information in War, with specific reference to Egypt's Attack on Israel on 6 October 1973.
\end{abstract}

Strategic surprise occurs to the degree that the victim does not appreciate whether he is attacked (moral surprise), or when, where or how the adversary will strike (material surprise). The effect of surprise is both psychological and physical, because the victim's moral, as well as his forces and equipment are destroyed. Surprise is an effective force multiplier, but it is not a guaranty for success. It creates an initial advantage that will not lead to success if it is not exploited. Successful deception is an effective way to ensure surprise. The enemy can be deceived with regard to capabilities, or if the capabilities are already known, with regard to the intention to use that capability. Through deception the enemy's thoughts are influenced. If his thoughts are influenced, his decisions and actions are influenced.

Surprise is prevented through an accurate determination of the existence and nature of a threat (enemy capabilities and intentions). The collection of information is seldom a problem, but the interpretation of information can easily go wrong. A number of factors influenced the interpretation of information: an inability to distinguish between 'signals' and 'noise'; a purposive enemy deception; perceptions, experience and expertise, as well as the particular situation. Why did Egypt succeed in surprising Israel in spit of Israel's knowledge of a possible Egyptian attack? This question can only be answered through an understanding of Egypt's deception plan and Israel's misinterpretation of information.

\section{Inleiding}

Sun Tzu (500 v.C.) maak in sy boek "The Art of War" die volgende stelling: "Thus, the reason the enlightened ruler and the wise general conquer the enemy whenever they strike is foreknowledge" (Hanzhang 1993 : 86). Die kennis waarna hier verwys word, is kennis van die vyand sowel as eie magte, want hy skryf verder: "Know the enemy and know 
yourself: in a hundred battles you will never be defeated". Hierdie siening is vandag nog net so geldig soos eeue gelede. Kennis van 'n opponent stel 'n moondheid, as alle ander faktore gelyk is, in staat om 'n beleid te formuleer wat die opponente sal ontmoedig om aggressief teenoor hom op te tree of, indien die opponent wel tot aggressie oorgaan, hom sal uitoorlê.

Die verkryging van hierdie kennis is egter nie so eenvoudig soos dit klink nie en volledige kennis van 'n opponent is feitlik 'n onvervulde droom. Kennis van 'n opponent skep vir 'n moondheid die geleentheid om sy opponent voor te spring en te verras. Hierdie optrede vind nie in isolasie plaas nie, want 'n opponent poog ook om kennis van jou optrede te bekom. Die kuns is gevolglik daarin geleë om soveel as moontlik kennis van die vyand te bekom, kennis van jou eie optrede van hom te weerhou of om hom van vals kennis te voorsien en dan die vyand met eie optrede voor te spring. Die konsepte van verrassing, misleiding en vertolking van informasie is onderliggend aan sodanige optrede.

Die doel van hierdie artikel is om die vraagstuk van misleiding, verrassing en vertolking van informasie in oorlog te ontleed, ten einde te bepaal watter rol dit in Egipte se aanval op Israel op 6 Oktober 1973 gespeel het. Die artikel word in twee dele verdeel. Die eerste deel is 'n konseptuele opheldering van die konsepte verrassing, misleiding en vertolking van informasie, ten einde die belangrikste problematiek verbonde aan die gebruik van misleiding en verrassing en die vertolking van informasie in 'n oorlog, uit te lig. Die tweede deel van die artikel fokus op die manifistasie van hierdie probleme in die praktyk, deur Egipte se aanval op Israel (6 Oktober 1973) onder die soeklig te plaas. Tegnologie speel, veral in die moderne era, 'n sentrale rol in verrassing, misleiding en die vertolking van informasie. Dit word weens die omvang daarvan nie pertinent in hierdie artikel aangespreek nie.

\section{Verrassing as 'n magsvermenigvuldiger}

Verrassing en misleiding is twee konsepte wat algemeen met oorlog geassosieer word en die geskiedenis dui aan dat hierdie assosiasie nie verkeerd is nie. Dit is eenvoudig logies om te redeneer dat suksesvolle misleiding geleentheid skep om ' $n$ opponent te verras. Alhoewel misleiding nie die enigste bron van verrassing is nie, is daar 'n definitiewe verband tussen die manifestasie van hierdie twee fenomene in oorlog.

Volgens R.K. Betts (1982: 4) word strategiese verrassing verkry tot die mate wat die vyandelike moondheid nie waardeer dat hy wel aangeval gaan word nie, of dat hy nie weet wanneer, waar en hoe hy aangeval gaan word nie. Uit hierdie definisie van Betts moet twee aspekte beklemtoon word. Eerstens is dit duidelik dat verrassing die gevolg is van onverwagse of onverwagte optrede. Tweedens blyk dit dat onverwagte optrede die resultaat kan wees van drie moontlike handelswyses. Die vyand kan verras word deur die tyd van optrede (wanneer), deur die keuse van die plek van optrede (waar) en deur die wyse waarop daar teen hom opgetree word (hoe).

Die siening dat verrassing die gevolg kan wees van onverwagse en onverwagte optrede is in ooreenstemming met J.F.C. Fuller (Simpkin $1994: 182$ ) se siening dat 
verrassing verder verdeel word in morele en materiële verrassing. Morele verrassing word verkry indien die vyand nie weet dat hy aangeval gaan word nie (onverwagse optrede deur diegene wat verrassing wil bewerkstellig). Israel het morele verrassing verkry in hul lugaanval op Egipte tydens die aanvang van die Sesdaagse Oorlog (5 Junie 1967). Materiële verrassing word verkry indien die vyand wel weet dat hy aangeval gaan word, maar niks kan doen om dit te voorkom, te keer of te beëindig nie (onverwagte optrede deur diegene wat verrassing wil bewerkstellig). (Simpkin 1994: 182) Die Geallieerdes het tydens die D-dag landings by Normandië op 6 Junie 1944 materiële verrassing bewerkstellig.

R.E. Simpkin onderskei tussen verrassing op die strategiese', operasionele ${ }^{2}$ en taktiese $^{3}$ vlak van oorlog, asook tussen die sielkundige en fisiese effek van verrassing. Die effek van verrassing is sielkundig tot die mate waartoe dit die moreel van die vyand (negatief) beïnvloed. Die effek is fisies tot die mate wat verrassing 'n mag in staat stel om die vyand hoër personeel- en uitrustingverliese toe te dien. Morele verrassing kan gevolglik op elke vlak van oorlog verkry word en die sielkundig en fisies effek daarvan kan ook op elke vlak manifisteer. Dieselfde geld vir materiële verrassing. Indien die drie wyses van verrassing (tyd, plek en metode) hierby gevoeg word, bring dit 'n model na vore wat diagrammaties voorgestel kan word (Sien figuur 1).

Die rede vir die deurslaggewende belang en aard van verrassing in oorlog moet in die effek van verrassing gesoek word. Vanuit 'n sielkundige oogpunt is dit duidelik dat verrassing die vyandelike moreel beïnvloed deur die skokeffek wat dit op die vyandelike magte en bevelvoerders tot gevolg het. (Betts 1982: 5) Carl von Clausewitz sien dit soos volg: "Surprise therefore becomes the means to gain superiority, but because of its psychological effect it should also be considered as an independent element. When it is achieved on a grand scale, it confuses the enemy and lower his morale." (Clausewitz 1984 : 42)

Die fisiese effek van verrassing is meestal 'n groot motivering vir 'n moondheid om van verrassing gebruik te maak. Verrassing is 'n groot magsvermenigvuldiger aangesien dit 'n geleentheid skep om 'n groot deel van die vyandelike mag (personeel en uitrusting) by die aanvang van 'n oorlog of operasie te vernietig (Betts 1982:5). Sodoende word 'n voordeel verkry wat ' $n$ moondheid of mag nie sou gehad het indien verrassing nie verkry is nie. Dit is verstaanbaar dat 'n moondheid of mag wat ' $n$ groot vyand in die gesig staar, hom tot verrassing sal wend om hierdie ongelykheid uit te wis. In die geval waar magte of moondhede van gelyke sterkte is, sal die een wat hom tot verrassing wend die voordeel behaal.

1 Naveh sien die strategiese vlak van oorlog as die hoër of abstrakte vlak wat betrekking het op die "building of military forces and their preparation for war, as well as with the general planning of armed conflict and its conduct" (Naveh 1997: 1).

2 Die veldhandleiding van die Amerikaanse leër (FM 100-5, 1976) definieer die operasionele vlak as "the employment of military forces to attain strategic goals in a theatre of war or theatre of operations, through the design, organization, and conduct of campaigns and major operations". Naveh beskou dit as volg: "The essence of this level, as the intermediary field between strategy and tactics, is the preparation, planning, and conduct of military operations in order to attain operational objectives and strategic aims (Naveh 1997: 9-10).

3 Die taktiese vlak van oorlog omsluit al die aktiwiteit wat plaasvind binne die geveg in kontak met die vyand. Naveh omskryf dit as volg: "The lower, or mechanical level, centred on the actual operation of the military forces on the battlefield" (Naveh 1997: 1). 


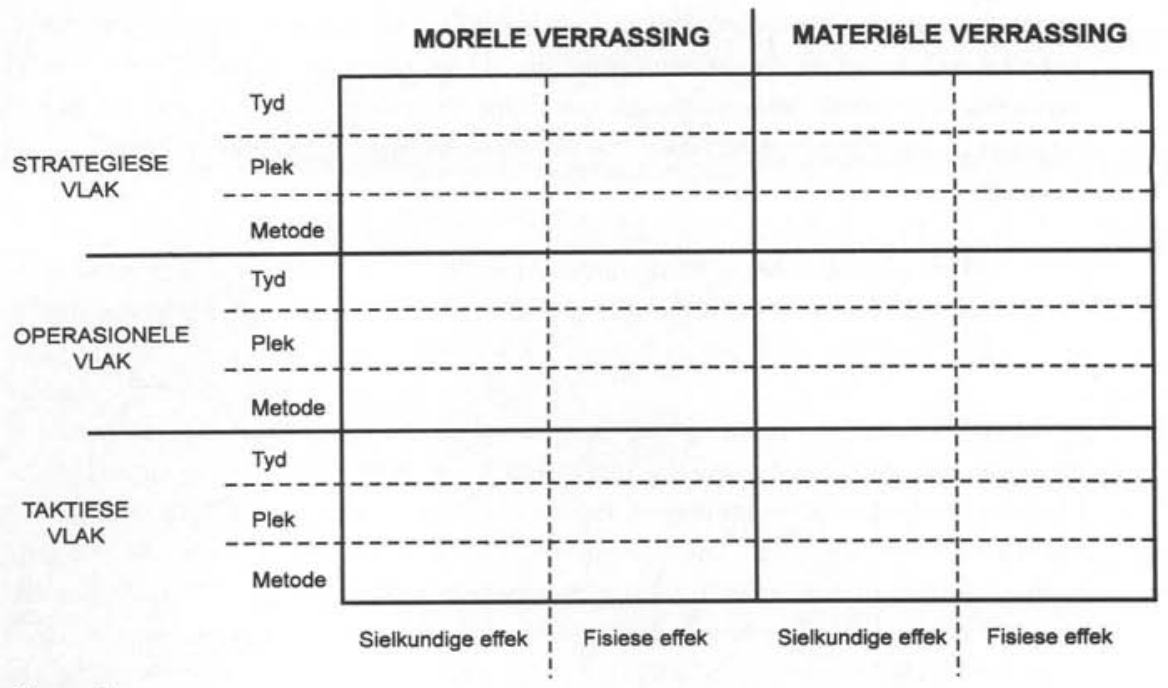

Figuur 1.

In gevalle waar moondhede nie die vermoë het om hul doelwitte te bereik deur die overte gebruik van mag alleen nie, kan die besluit om tot oorlog oor te gaan of die vyand aan te val en die besluit om verrassing te gebruik, nie onafhanklik van mekaar oorweeg word nie (Hybel $1986: 26$ ). In so 'n geval kan die besluit om tot oorlog oor te gaan, juis afhang van die vermoë om verrassing te bewerkstellig.

In gevalle waar verrassing nie voldoende is om die ongelykhede in moondhede of magte se vermoëns uit te wis nie, is daar, volgens A.R. Hybel (1986 : 26-27), verskeie faktore van belang. 'n Land se kultuur en waardestelsel het ' $n$ invloed. Weens verskille in waardes ervaar, evalueer en reageer mense uit verskillende kulture, verskillend op bedreigings. Kulturele oorwegings kan gevolglik ' $n$ invloed uitoefen op ' $n$ moondheid of mag se besluit om van verrassing gebruik te mak. Die gevolge van 'n besluit om nie van ' $n$ verrassingsaanval gebruik te maak nie, speel ook 'n rol. Indien die gevolge van 'n besluit om nie verrassing te gebruik nie, 'n groter negatiewe effek op 'n moondheid of mag sal hê as in die geval waar hy wel verrassing gebruik, kan dit daartoe lei dat die gebruik van verrassing gunstig oorweeg sal word. Dit is een van die verklarings wat verskaf word vir Japan se aanval op die VSA in Desember 1941. Hybel (1986:31) stel dit soos volg:

"Many of Japan's decision makers were fully aware that engaging in a war with the United States was an endeavor of great uncertainty. Nevertheless, they also felt that losing status and failing in the traditional goal of establishing Japan as hegemonic force in the Far East was worse than risking the possibility of losing a war."

Dit is naïef om te aanvaar dat 'n moondheid of mag wat daarin slaag om sy opponent te verras, verseker sal wees van 'n oorwinning. Dit mag wees dat die vyand in sekere gevalle so oorweldig is deur die omvang van die verrassing, dat hy totaal lamgelê is en dat die 
verrasser verseker is van 'n oorwinning. In baie gevalle skep verrassing slegs 'n aanvanklike voordeel wat, indien dit nie uitgebuit word nie, nie tot sukses sal lei nie. Die gebruik van verrassing is gevolglik 'n goeie metode om 'n geleentheid yir verdere optrede te skep en inisiatief en handelingsvryheid vir verdere optrede te bekom. M.I. Handel (1984: 230) merk tereg op:

"Thus, accomplishment of the surprise itself is only the first phase of planning; the second must consist of detailed preparations for the best possible exploitation of the projected surprise attack".

Die sukses van verrassing hang gevolglik af van die impak daarvan op die vyand en die suksesvolle uitbuiting van hierdie impak. Die fisiese effek van verrassing omvat meer as bloot die vernietiging of neutraliseering van die vyandelike vermoë (mannekrag en materiaal) voordat dit benut kan word. Dit ontneem die vyand ook die vermoë om sy eie planne in werking te stel. K. Brodin (1978 : 99) vertolk derhalwe verrassing as "an attack launched against an opponent who is insufficiently prepared in relation to his potential (mobilization) resources". Die onvoorbereidheid van die vyand om sy eie planne in werking te stel, kan 'n deurslaggewende faktor in die suksesvolle uitvoering van verrassing wees.

Wat veroorsaak dat 'n moondheid of mag onbewus is van 'n dreigende aanval en gevolglik onvoorbereid is? Eerstens kan dit wees dat 'n moondheid of mag nie bewus is van 'n bedreiging nie. Onvoorbereidheid kan dus die resultaat wees van 'n gebrek aan inligting. Tweedens kan dit wees dat 'n staat of mag wel bewus is van ' $n$ bedreiging. In so 'n geval beskik ' $n$ staat wel oor inligting wat daarop dui dat daar 'n bedreiging bestaan. Onvoorbereidheid kan dan eerstens die resultaat wees van die verkeerde vertolking van informasie wat ontvang word. Tweedens kan dit moontlik wees dat die informasie wat ontvang word, korrek vertolk word, maar dat daar 'n doelbewuste misleidingspoging deur die vyand geloods word wat daarop dui dat hy nie van voorneme is om aan te val nie. Misleiding en die vertolking van informasie staan gevolglik sentraal in die verkryging van verrassing al dan nie.

\section{Misleiding as 'n wyse om verrassing te verkry}

Verskillende denkers het verskillende sienings oor presies wat misleiding is. Volgens D.C Daniel en K.L Herbig (1982 : 155) is misleiding 'n doelbewuste wanvoorstelling van die werklikheid "to gain a competitive advantage". Simpkin (1994: 195) beskou dit as maatreëls "superimposed on a genuine capability to enhance the chance of success". Beide hierdie twee sienings dui daarop dat misleiding te doen het met werklike vermoëns. Hierdie feit laat die gebruiker van misleiding met twee basiese keuses. Eerstens kan misleiding gebruik word om ' $n$ moondheid of mag se ware vermoëns vir die vyand te verberg. Tweedens is dit moontlik dat die ware vermoëns reeds aan die vyand bekend is of dat die moontlikheid groot is dat die vyand die ware vermoëns kan bepaal. In so 'n geval sal misleiding slegs suksesvol wees indien die voorneme om die vermoëns te gebruik vir die vyand verberg word. Die vyand word in so 'n geval mislei ten opsigte van die moontlikheid, tyd, plek en metode van 'n aanval. 
Simpkin (1994 : 189) wys daarop dat sekerheid 'n groot rol speel in die uitvoering van misleiding. Sekerheid word gesien as die passiewe komponent van misleiding en behels, volgens Simpkin, die passiewe verdediging van informasie. Sekerheid kan omskryf word as die toestand wat voortspruit uit die instelling van maatreëls wat die informasie, personeel, stelsels, komponente en uitrusting van ' $n$ mag beskerm teen vyandelike persone, handelinge of invloed". Die informasie waarna Simpkin verwys, het betrekking op ' $n$ staat se voornemens en vermoëns. In die geval van misleiding het sekerheid 'n groter rol om te vervul. Deur sekerheid moet die feit dat misleiding op 'n land toegepas word, ook verberg word. Dit kan gedoen word deur die gebruik van 'n goeie dekstorie. 'n Dekstorie ${ }^{5}$ kan omskryf word as 'n fiktiewe aanvaarbare verklaring wat gedoen word om die ware doelstellings en aktiwiteite van 'n operasie te verberg.

Die benutting van sekerheid om 'n misleidingspoging vir die vyand te verberg deur die gebruik van ' $n$ goeie dekstorie, kan selfs die aanwending van ' $n$ moondheid se eie magte beinvloed. Dit mag vereis dat selfs eie magte mislei moet word om die misleidingspoging suksesvol uit te voer. Die gebruik van misleiding vereis gevolglik goeie beplanning en organisasie, terwyl die uitvoering goed gekoördineer moet word. Volgens Handel (1982 : 133) hang die uitvoering van die aktiewe komponent van misleiding af van die sukses van passiewe misleiding.

Die aktiewe komponent van misleiding behels 'n openbaarmaking van halwe waarhede wat deur die vyandelike inligtingsisteme "ingesamel" moet word. Die vyand moet die "ontdekking" van die informasie self doen. Dit beteken dat enige informasie wat op hierdie wyse aan die vyand "voorsien" word, deur verskeie "bewyse" gesteun moet word om dit geloofwaardig vir die vyand te maak (Handel $1982: 134$ ). Om hierdie rede is dit makliker om misleiding suksesvol uit te voer indien 'n bestaande vyandelike wanpersepsie of vooroordeel versterk kan word deur die "voorsiening" van halwe waarhede wat hierdie wanpersepsie of vooroordeel versterk.

'n Deeglike kennis van die vyand se denke, karakter, kultuur en omstandighede is gevolglik 'n voorvereiste vir suksesvolle misleiding. Die moondheid wat van misleiding gebruik maak, moet oor die vermoë beskik om die gegewe situasie vanuit die vyandelike oogpunt te ontleed. Daarbenewens moet die moondheid ook ' $n$ deeglike kennis van die vyandelike insamelingsvermoë hê. Dit is daardie element van die vyandelike inligtingsorganisasie wat die misleiding moet "ontdek" sodat die misleiding suksesvol kan wees.

Volgens Handel word misleiding om drie redes uitgevoer. Eerstens word gepoog om die vyand se aandag te verplaas, sodat sy magte op die verkeerde plek gekonsentreer is. Tweedens kan dit ten doel hê om die vyand te dwing om die beginsel van ekonomiese aanwending van mag te skend. Die vyand moet sy skaars hulpbronne aanwend en vermors op aspekte wat nie van deurslaggewende belang is nie. Laastens word misleiding uitgevoer om

Militêre Woordeboek van die SAW: pp 289

Militêre Woordeboek van die SAW: pp 71 
te verras en 'n situasie te skep waarin die vyand onvoorbereid is vir aksie (Handel 1982 : 124 \&125). Daar kan geargumenteer word dat die skrywer se siening nie suiwer is nie. Die eerste twee redes is niks anders as die skep van situasies waarin die vyand onvoorbereid is vir aksie nie. Sodanige situasies word vereis om verrassing suksesvol uit te voer. Die enigste rede waarom misleiding uitgevoer word, is om die onvoorbereidheid van die vyand te verseker ten einde hom te verras.

B.H. Liddell Hart (1967: 323) argumenteer dat die menslike wil die grootste bron van weerstand in ' $n$ oorlog is. Deur misleiding word gepoog om die vyand se denke te beïnvloed. Indien die vyand se denke beïnvloed kan word, kan sy besluite en optredes beïnvloed word. Waar die vyand se denke en besluite so beïnvloed kan word dat sy optredes situasies skep waarin hy onvoorbereid is vir aksie, het misleiding in sy doel geslaag. Waar sodanige situasies bestaan, is die kanse goed dat verrassing suksesvol uitgevoer kan word.

Suksesvolle misleiding en verrassing beteken by implikasie dat die moondheid wat mislei en verras word, nie weet van die bedreiging of potensiële bedreiging wat bestaan nie, of indien hy bewus is van ' $n$ bedreiging, dat hy nie weet waar, wanneer en hoe die vyand gaan optree nie. So 'n gebrek aan kennis kan die totale voortbestaan van 'n moondheid in gevaar stel. Daarteenoor benodig 'n staat wat van misleiding en verrassing gebruik wil maak kennis van sy potensiële slagoffer. Hierdie kennis, of gebrek, daaraan is bekend as inligting.

\section{Die Vertolking van informasie}

W.V. Kennedy definieer inligting as "the gathering of information that can enable a government to gain advantages over rivals or competitors, or at least to survive. Intelligence is the processing, or analysis, of information to determine how much of it should be passed on as useful and reliable" (Kennedy, 1983: 15). In hierdie definisie kom twee belangrike aspekte na vore. Die een is die verskil tussen inligting en informasie en die ander is die inligtingsproses.

Inligting is die produk van insameling, evaluering, ontleding, integrasie en vertolking van alle beskikbare informasie wat vir gebruik versprei kan word (Militêre Woordeboek SAW: 148). Dit is duidelik dat alle ongeëvalueerde materiaal wat by ontleding inligting produseer as informasie beskou kan word. Inligting kan kortliks as vertolkte informasie gesien word. Die inligtingsproses bestaan uit die insameling van informasie, die verwerking van hierdie informasie tot inligting en die beskikbaarstelling van hierdie inligting aan die verbruiker. Slegs in uitsonderlike gevalle word probleme ondervind met die insameling of verkryging van informasie, sowel as die verspreiding van inligting. Probleme wat ontstaan op die gebied van inligting, hou gewoonlik verband met die verwerking, of soos dit algemeen bekend is, die vertolking, van informasie.

Volgens K. Knorr (1979: 70) is die doel van inligting om te bepaal of 'n bedreiging bestaan en tweedens, wat die presiese aard van die bedreiging is. Daar is reeds aangedui dat ' $n$ bedreiging uit twee komponente bestaan. Vir een moondheid om ' $n$ bedreiging vir ' $n$ ander in te hou, moet dit oor 'n bepaalde militêre vermoë beskik. Dit moet, tweedens, ook 'n 
voorneme hê om sodanige vermoë aan te wend. Slegs deur te bepaal wat 'n opponent se vermoëns en voornemens is, kan die bestaan en aard van 'n bedreiging bepaal word.

Die vraag wat nou na vore kom, is hoekom lande wat oor voldoende informasie van 'n opponent se vermoëns en voornemes beskik, nie 'n akkurate waardering van 'n werklike of potensiële bedreiging kan mak nie. Die eerste aspek wat Knorr in hierdie verband beklemtoon, is inligtingsgemeenskappe se onvermoë om te onderskei tussen "signals" en "noise" in hul vertolking van informasie. Wanneer ' $n$ groot hoeveelheid informasie deur inligtingsagentskappe vertolking word, raak dit baie moeilik om te onderskei tussen "seine" en "geraas". In retrospek is dit gewoonlik maklik om te onderskei tussen korrekte en irrelevante of vals informasie (Knorr 1979: 74).

Die vertolking van informasie word verder gekompliseer deur die moontlikheid dat 'n opponent doelbewus vals informasie kan voorsien om sy misleidingsplan suksesvol uit te voer. Voorts kan besluitloosheid van 'n opponent, terwyl hy met dreigende optrede besig is, die vertolking bemoeilik (Knorr 1979 : 74). 'n Moondheid se optrede is gewoonlik geskoei op verskillende moontlike optredes wat aan bepaalde senario's gekoppel is. ' $\mathrm{n}$ Moondheid mag. byvoorbeeld, besluit om sy opponent aan te val slegs indien spesifieke omstandighede geskep word, of ' $n$ bepaalde senario ontstaan. Daar word dikwels na só ' $n$ senario verwys as die 'offensiewe drumpel'. In so 'n geval het inligtingsorganisasies ' $n$ baie uitdagende taak om die aard van die vyandelike voorneme te bepaal.

Die vertolking van informasie word uitgevoer deur mense met verskillende sienings, ervarings en verwysingsraamwerke, sodat hul beskouing van spesifieke gebeurtenisse van mekaar verskil. Vooroordele ontstaan binne inligtingsorganisasies as gevolg van aannames wat gemaak word op grond van die opponent se optrede en gedrag in die verlede (Knorr 1979 : 75). Dit is verstaanbaar dat vooroordele en verwagtings van ' $n$ opponent se optrede en gedrag sal ontstaan indien sodanige optrede en gedrag oor ' $n$ verloop van tyd ' $n$ bepaalde patroon openbaar. Vooroordele en sienings word ook deur aspekte soos emosies, ideologieë, burokrasie en wensdenkery beïnvloed. A. Shlaim (1976:360) maak selfs melding van die rol wat groepsdinamika speel binne inligtingsorganisasies. Dit lei daartoe dat lede van 'n groep neig om gevare mis te kyk, konformerend op te tree en 'n optimistiese uitgangspunt te ondersteun, of andersom. Inligtingspersoneel moet, as individue, voortdurend hierteen waak.

Die aard van die situasie waarin die vertolkers van informasie hulself bevind, beïnvloed die vertolking daarvan (Knorr 1979 : 79). Dit is veral in krisistye dat aspekte soos die klem op die vinnige beskikbaarstelling van informasie en stress ' $n$ invloed kan hê op die vertolking van informasie.

"Seine": Feite of informasie wat bydra tot " $n$ korrekte waardering van die bedreiging.

"Geraas": Informasie wat nie bydra tot 'n korrekte waardering van die bedreig nie, of wat totaal irrelevant is met betrekking tot die betrokke situasie. 
Volgens Knorr (1979: 80) gee inligting van die vyand se vermoëns 'n goeie aanduiding van die presiese omvang van 'n bedreiging. Hierdie stelling is waar in dié mate dat 'n kwantitatiewe analise 'n aanduiding is van 'n land se vermoë. Dit is relatief maklik om te bepaal oor hoeveel tenks, divisies, vliegtuie, aanvalsvaartuie, ensovoorts, 'n land beskik. 'n Kwalitatiewe ontleding van 'n land se vegvermoë is egter nie so maklik om uit te voer nie. Kwalitatiewe aspekte, soos moreel, opleiding, leierskap en die wil van die bevolking is moeiliker om presies te bepaal. 'n Kwalitatiewe ontleding van 'n opponent se vermoëns word gewoonlik uitgevoer in verhouding tot jou eie vermoëns, aangesien daar nie werklik 'n maatstaf is om hierdie aspekte te meet nie. Vooroordele van vertolkers kan die sienings van die vyandelike kwalitatiewe vermoëns beïnvloed. Verskeie van hierdie faktore het bygerdra tot Egipte se suksesvolle verrassing van Israel op 6 Oktober 1973.

\section{Egipte se aanval op Israel, 6 Oktober 1973}

Egpite en Sirië het om 14 h00 op 6 Oktober 1973, 'n Joodse godsdienstige vakansiedag, 'n suksesvolle verrassingsaanval teen Israel geloods. Die verrassing wat behaal is, het Egipte in staat gestel om die Suezkanaal op verskeie plekke sonder enige noemenswaardige Israeli teenstand oor te steek. Israel is selfs verras deur die vernuftige wyse waarop Egiptiese ingenieurs waterpompe gebruik het, om die grondfortifikasies wat Israel op die oostelike oewer van die kanaal opgerig het, te oorkom. Reeds op 7 Oktober het Egipte magte langs die totale lengte van die Suezkanaal ontplooi gehad, met die uitsondering van die gebied noord van die Groot Bitter Meer. Teen 10 Oktober was die Egiptiese Magte sowat $16 \mathrm{~km}$ vanaf die kanaal in verdedigingstellings ontplooi. Die verrasing is verhoog deur die effektiewe wyse waarop die Egiptiese magte hul stellings met lug- en tenkafweer wapens beskerm het. Dit het Israeli teenaanvalle suksesvol afgeweer, aangesien dit die swaartepunt van die Israeli magte, lugkrag en mobiele oorlogvoering met pantsermagte, geneutraliseer het. (Dupuy 1982: 40-42)

Israel het wel oor voldoende informasie beskik wat daarop gedui het dat ' $\mathrm{n}$ aanval dreigend was. Die Arabiese magte het ten spyte hiervan, steeds daarin geslaag om Israel suksesvol te verras. Wat het daartoe gelei dat dat Israel onvoorbereid was op die vyandelike aanval en dat Egipte suksesvol was in die verkryging van verrassing?

\section{Egipte se beplanning vir die oorlog}

Die oorsprong van die Oktober-oorlog kan na die Arabiese neerlaag in die Sesdaagse Oorlog (1976) teruggevoer word. Ten einde verlore Arabiese grondgebied en aansien te herwin, het president A. Sadat van Egipte ná die Sesdaagse Oorlog 'n langtermynstrategie, geskoei op politieke en militêre aksies, in die vooruitsig gestel. Druk vanuit ander Arabiese state, sowel as ekonomiese en sosiale probleme in Egipte het Sadat egter gedwing om na ' $n$ geweldadige oplossing vir probleme in die Midde Ooste te begin soek. Dit het hom voor die probleem te staan gebring dat Israel militêr magtiger as Egipte en Sirië was.

Egipte het intussen die struikelblokke van die Sesdaagse Oorlog aangespreek. Ten einde Israel se lugoormag die hoof te bied, sou 'n "muur" van lugafweermissiele langs die 
Suezkanaal opgerig word. Die Israeli-pantserbedreiging sou deur 'n groot konsentrasie van tenkafweerwapens in Egipte se gewapende magte teengestaan word. Die probleem wat vir Egipte geskep is deur Israel se uitstekende vermoë om reserwes vinnig te mobiliseer, moes met die gebruik van verrassing geneutraliseer word (Herzog $1984: 229$ ).

Sadat het die voordele van verrassing besef, maar was ook realisties genoeg om te besef dat Israel te sterk was om deur 'n verrassingsaanval vernietig te word. Hy het gevolglik besluit om nie te poog om Israel te verslaan nie, maar om deur sy militêre optrede die MiddeOoste te destabiliseer, ten einde 'n bedreiging vir Amerikaanse en Sowjet détente te skep (Hybel 1986 : 39). Die politieke invloed van die Sowjet Unie sou gebruik word om druk op die Verenigde Nasies toe te pas om 'n skietstilstand te bewerkstellig, indien die aanval sleg verloop òf om inmenging te verhoed indien alles voorspoedig verloop (Herzog $1984: 229$ ). Supermoondheidsinmenging in die konflik moes gebruik word om Israel te dwing om die grondgebied wat met die Sesdaagse Oorlog beset is, aan Egipte terug te gee (Hybel 1986 : 39).

Sadat het op ' $n$ vroeë staduim die samewerking van President Assad van Sirië in die beplanning van die aanval verkry. In Augustus 1973 is daar met die finale beplanning van die aanval begin. Die 6de Oktober is om twee redes as D-dag ${ }^{8}$ gekies. Eerstens was dit ' $n$ Joodse godsdienstige vakansiedag (Yom Kippur) in Israel. Tweedens sou dit saamval met gunstige getye en strome in die Suezkanaal ' $n$ brugkruisingsoperasie oor die kanaal te vergemaklik (Herzog 1984 : 229). Die aanval sou egter deur 'n grootskaalse misleidingspoging voorafgegaan word.

\section{Egipte se uitbuiting van Israel se vooroordele deur misleiding}

Egipte se misleidingsplan was suksesvol in die bevestiging van Israel se wanpersepsies en vooroordele op 'n politieke en militêre vlak. Israel het nie die moontlikheid voorsien dat die Arabiere 'n oorlog om beperkte doelwitte sou veg nie. Soos Betts (1992 : 70) dit stel: "Israeli's and Americans did not consider that a military solution short of the defeat of Israel could produce results worth the losses to the Arabs". Die inligtingsgemeenskap in Israel het hul evaluasie van informasie op twee aannames geskoei. Eerstens is aanvaar dat Egipte nie ' $n$ aanval sou loods voordat sy lugmag in 'n posisie was om Israel se lugmag te neutraliseer deur aanvalle Israeli lugmagbasisse nie. Israel was tweedens van mening dat Sirië nie 'n aanval sou loods sonder Egipte se steun nie (Cohen \& Gooch 1990 : 114). Die moontlikheid van 'n aanval deur Sirië voordat 'n ooreenkoms tussen Egipte en Sirië tot stand gekom het, was volgens Israel baie klein. Israel was van mening dat Egipte eers teen 1975 oor die militêre vermoë sou beskik om hierdie aanvalle te kon loods. (Herzog 1984: 227-228)

Volgens Betts (1982: 70) het Israel, weens sy ervarings in die Sesdaagse Oorlog en vroeër, 'n persepsie van die Arabiese soldaat gehad as primitief, ongedissiplineerd en nie in staat om gesofistikeerde uitrusting te hanteer en gekoördineerde, geïntegreerde operasies te

8 Militêre term wat die dag waarop ' $n$ operasie in aanvang neem, aanduı. 
loods nie. In Israel is daar geen poging aangewend om die verbeteringe in opleiding en uitrusting wat ná 1967 gemaak is, te oorweeg nie.

Egipte was bewus van hierdie vooroordele wat in Israeli-geledere bestaan het en het verskeie pogings aangewend om dit te versterk. Die samewerkingsooreenkoms tussen Egipte en Sirië is in die geheim gesluit, terwyl hulle in die openbaar verklaar het dat samewerking tussen hulle, weens onoorkomlike probleme, nie moontlik was nie. Beide Sirië en Egipte het hul beperkte doelwitte en die verbetering van hul militêre vermoëns vir Israel verberg. Israel was byvoorbeeld onbewus dat Egipte nuwe middele en metodes vir die oorsteek van die kanaal bekom het. Egipte en Sirië het hul planne om Israel se tenk- en lugkrag te neutraliseer deur van lug- en tenkafweerwapens gebruik te maak, geheim probeer hou (Hybel 1986 : 7678).

Egipte was suksesvol in die skepping van 'n patroon van optrede deur herhaaldelike mobilisasie van sy gewapende magte, sonder dat dit op oorlog uitgeloop het nie. Tussen Desember 1971 en April-Mei 1973 het Egipte drie keer gemobiliseer vir oorlog. Elke keer is die magte gedemobiliseer sonder dat gewapende konflik uitgebreek het. Tydens die mobilisasie in April-Mei 1973 het Israel in reaksie ook 'n deel van sy magte op bystand geplaas. Israel is gevolglik nie ontstel deur Egipte se mobilisasie in September 1973 nie. Betts wys daarop dat daar selfs aanduidings was dat die mobilisasie met minder erns bejeën is. Egipte en Sirië se burgerlike beskerming is nie geaktiveer nie; daar was geen sigbare bewyse dat die Arabiese bevolkings hulself gereed gemaak het vir 'n oorlog nie; die mobilisasie-order het aangedui dat Egipte se burgermag teen 8 Oktober vrygestel sou word vir demobilisasie (Betts 1982: 73).

Die voorbereidings in Sirië is beskou as 'n reaksie op 'n luggeveg met die Israelilugmag op 13 September 1973 waartydens 13 Siriese vliegtuie afgeskiet is. Israel het die hoë vlak van gereedheid van die Egiptiese magte verklaar as synde die normale stand van sake te wees by 'n oefening van die omvang waarmee Egipte se gewapende magte op daardie tydstip besig was. Voorts is die oefening gesien as 'n poging om Israel af te skrik om nie militêre optrede teen Sirië te loods nie. Die Direkteur van Militêre Inligting, genl. E. Zeira, het tot die gevolgtrekking gekom dat die moontlikheid van 'n aanval baie skraal was (Stein 1982 : 109).

Egipte was egter nie net suksesvol in sy misleidingspoging deur die bevestiging van Israel se vooroordele nie. Die inligtingsgemeenskappe in Israel is ook verwar deur informasie en gebeure van 'n uiteenlopende aard, waardeur Egipte geslaag het in die skepping van "geraas".

\section{Egipte se sukses in die skepping van "geraas"}

Behalwe die gebruik van die mobilisasie en demobilisasie van sy magte om Israel te verwar, het verskeie Egiptiese optredes "geraas" in die Israeli-inligtingsgemeenskap geskep, sodat dit feitlik onmoontlik was om tussen korrekte en valse of misleidende informasie te onderskei. Met beide die Egiptiese en Siriese weermagte gemobiliseer, was die Israeliinligtingspoging gefokus op die bepaling van die voornemens van die Arabiese magte. 
Ten spyte van die mobilisasie, het Egipte die Verenigde State van Amerika se vredesinisiatiewe in September 1973 in die openbaar verwelkom. Voorts het Egipte die media by sy misleidingspogings betrek. Nuus oor die verwaarlosing en agteruitgang van die Russiese uitrusting wat deur Egipte in die Kanaalgebied gebruik is, het in die Libanese pers verskyn (Shlaim 1976 : 355). Die media het verklarings van genl. M. Dayan met betrekking tot die onvoorbereidheid van Egipte, asook 'n analise van genl. Y. Rabin waarin die moontlikheid van oorlog gering geskat is, breedvoerig gedek. Selfs 'n Britse oorlogskorrespondent het die swak onderhoud en onvoorbereidheid van die Egiptiese leër beskryf (Herzog 1984 : 228).

Sowat 95 persent van die Egiptiese offisiere wat Israel tydens die 1973-oorlog gevange geneem het, het die oggend van 6 Oktober 1973 vir die eerste keer gehoor dat die oefening 'n dekmantel vir 'n aanval teen Israel was (Herzog $1984: 229$ ). Dit is 'n aanduiding van die goeie sekerheid wat deur die Egiptiese magte, veral die bevelselement, gehandhaaf is. Dit is verder ' $\mathrm{n}$ aanduiding dat Egipte sy eie weermag by die misleidingspoging betrek het, ten einde die geloofwaardigheid van die poging te verseker.

Dit spreek vanself dat rapporterings deur die Israeli-magte in Sinai van Egiptiese aktiwiteite sou toeneem nadat Egipte met hul oefening begin het. Informasie van artillerie, uitrusting en ammunisie wat by Port Fouad ontskeep is, asook van artillerie wat vorentoe gebring is en missielstellings wat beman word, is ontvang. Rapporte het beskryf hoe toegangsweë na die kanaal verbeter is en voorbereidings getref is om die kanaal oor te steek. Soos Egiptiese magte myne op een plek in die kanaal opgelig het, het hulle dit by 'n ander punt gelê. Die normale daaglikse roetine langs die kanaal het voortgegaan. Burgerlikes het met hul werk voortgegaan asof hul niks te wagte was nie. Die Egiptiese soldate het in die kanaal visgevang en was op die oog af totaal ontspanne. (Herzog $1984: 235$ )

Volgens C. Herzog (1984: 237) was daar een element wat 'n duidelike aanduiding van 'n naderende oorlog vir die Israeli's moes gewees het: dit was die aktiwiteite van die Sowjet Unie in die Midde-Ooste kort voor die uitbreek van die oorlog. Drie dae voor die uitbreek van die oorlog is 'n Sowjet verkenningsateliet in 'n wentelbaan bo die Sinai geplaas. Op 4 Oktober het eenhede van die Sowjet vloot uit die hawens van Alexandria en Port Said begin beweeg. Informasie is ook ontvang van Sowjet vliegtuie wat begin het om burgerlikes van die Sowjet Unie uit Kaïro en Damaskus te ontruim.

Die tyd van die dag waarin die aanval uitgevoer is, het bygedra tot Egipte se verkrygying van verrassing. 'n Aanval soos dié wat deur Egipte uitgevoer is, word gewoonlik vroeg in die oggend van stapel gestuur. Deur die aanval om $14 \mathrm{~h} 00$ die middag van stapel te stuur, het gevolglik ook tot Egipte se verkryging van verrassing bygedra.

Dit is nie duidelik of die skaking van 'n trein vol Russiese Jode in Oostenryk op 29 September deel uitgemaak het van die Egiptiese misleidingspoging nie. Dit het egter effektief daarin geslaag om die Israeli-regering se aandag af te lei. Beide die Israeli regering en bevolking het op hierdie probleem gefokus en hul aandag is van ontwikkelinge langs die 
Suezkanaal af weggelei. Die vroegtydige staking van Egiptiese burgerlike lugvaart op 5 Oktober het ook 'n duidelik waarskuwing aan Israel verskaf. (Betts 1982: 76)

In retrospeksie is dit feitlik onverstaanbaar hoekom Issrael nie ag geslaan het op hierdie herhaalde aanduidings nie. Dit is duidelik dat daar nie enige gebrek aan informasie was nie. Hoekom kon Israel nie daarin slaag om 'n korrekte waardering van die situasie te maak nie?

\section{Israel se wanvertolking van informasie}

Israel se verdedigingskonsep was, weens sy onvermoë om 'n groot staande mag te bekostig, op drie konsepte geskoei: eerstens is op die inligtingsgemeenskap staatgemaak om voldoende waarskuwingstyd aan die gewapende magte te voorsien ten einde die reserwes te mobiliseer; tweedens moes die klein staandemagkomponent van die Israeli leër in staat wees om die vyandelike offensief te vertraag tot die reserwes gemobiliseer is; derdens het Israel oor 'n groot permanente lugmag beskik wat van die begin van enige oorlog af, offensief kon optree. In die geval van 'n aanval teen Israel moes hierdie drie elemente tyd wen en die front hou tot die reserwes gemobiliseer was en Israel gereed was om offensief op te tree. In Oktober 1973 het die belangrikste element van hierdie strategie misluk. Die inligtingsgemeenskap kon nie akkurate inligting wat voldoende waarskuwingstyd sou verskaf, voorsien nie. (Herzog $1984: 230$ ) Tesame hiermee is die Israeli lugkrag en pantsermagte ook tot ' $n$ groot mate geneutraliseer deur die Arabiese magte se gebruik van lug- en tenkafweerwapens wat vir die Israeli's verberg is.

Dit is baie duidelik dat Israel se inligtinggemeenskap 'n deurslaggewende rol in sy verdediging gespeel het. Israel se inligtingsgemeenskap het deur die jare vir hulle 'n reputasie van effektiwiteit opgebou. Die gevolg hiervan was dat beide die politici en senior militêre offisiere versigtig was om die inligtinggemeenskap te bevraagteken. Dié toedrag van sake blyk duidelik uit die Siman Tov-voorval, waar 'n luitenant op 1 en 3 Oktober rapporte aan die Suidelike Kommandement (in Sinai) voorgelê het, waarin die aanduidings van ' $n$ dreigend oorlog duidelik uiteengesit is. Hierdie rapport is egter nie verder versprei nie, omdat dit nie in ooreenstemming was met die hoër hoofkwartier se evaluasie van die situasie nie (Shlaim 1976 : 354). Luitenant Benjamin Siman Tov was die slagorde-offisier van die Suidelike Kommandement se inligtingsafdeling. In sy rapport van 1 Oktober het hy ' $n$ ontleding gemaak van die Egiptiese ontplooiings, as ' $n$ aanduiding dat Egipte besig was met voorbereidings vir ' $n$ oorlog. In sy verslag van 3 Oktober het lt. Siman Tov verskeie faktore, wat daarop dui dat Egipte besig was om die oefening as ' $n$ dekstorie vir ' $n$ aanval te gebruik, uitgewys. (Herzog 1984: 236)

Wat die politici se verhouding met die inligtinggemeenskap betref, was daar 'n wedersydse weerhouding van bevraagtekening. Die inligtingshoofde was nie onder politieke druk nie, maar was in gereelde, noue kontak met die ministers wat die besluite met betrekking tot nasionale veiligheid gemaak het. Die inligtingshoofde het nie die dogmas en vaste oortuigings van hierdie politici uitgedaag nie. Informasie, analises en waarderings is bewustelik of onbewustelik so aangepas, dat dit by politici se sienings en beleide ingepas het 
(Shlaim 1976 : 366). Genls. Zeira en Shalev het, byvoorbeeld, in hul kontak met die Israeli politici in die dae voor die aanval, erken het dat Egipte oor ' $n$ vermoë beskik om Israel aan te val, sonder vooraf waarskuwing. Dit is egter beklemtoon dat die moontlikheid skraal was dat dit wel sou plaasvind. (Herzog 1984: 234)

Die evaluasie van informasie is sterk beïnvloed deur vooroordele en wanpersepsies wat binne die inligtinggemeenskap bestaan het. Daar is reeds gewys op die feit dat Israel oortuig was dat Egipte nie sou aanval voordat dit nie die Israeli lugmag kon neutraliseer nie. Veral Genl Zeira, die Direkteur van Militêre Inligting, was sterk oortuig van hierdie siening. Hierdie oortuigings het daartoe gelei dat informasie en vyandelike ontplooiings gerasionaliseer is om by hierdie vooroordeel in te pas (Shlaim $1976: 353$ ). Hierdie oortuigings het verder daartoe bygedra dat slegs informasie wat by hul persepsies ingepas het, vertolk is. Informasie van Egipte se lug- en tenkafweerbedreiging is nie in 'n ernstige lig beskou nie of is geïgnoreer. Daar is, byvoorbeeld, geargumenteer dat die teenwoordigheid van Egiptiese leër langs die Seuz kanaal nie voldoende aanduiding was van 'n moontlike aanval nie. Sedert 1971 is die Egiptiese leër ook reeds drie maal ten volle gemobiliseer, sonder dat daar ' $n$ aanval uitgevoer is. (Herzog 1984: 234)

Dit is juis hierdie herhaalde mobilisasies en demobilisasies wat die inligtingshoofde gekondisioneer het. Dit het uitgeloop op 'n situasie, veral na die April-Mei 1973 mobilisasie, waar 'n mobilisasie nie meer as 'n bedreiging en 'n aanduiding van 'n moontlike aanval beskou is nie. Volgens Betts (1982 : 72) het "alert fatique" 'n groot rol gespeel in Israel se besluit in September 1973 om nie te mobiliseer nie, ten spyte van groeiende bewys van Egipte se gereedheid vir aksie.

Die inligtingsgemeenskap se nalating om 'n waarskuwing van 'n dreigende aanval te voorsien het ook daartoe gelei dat, veral die leër, onvoorbereid was. Gen Ariel Sharon wys byvoorbeeld in sy outobiografie daarop dat die verrassing aangehelp is deur die wyse waarop Israel se pantsermagte met die uitbreek van die oorlog ontplooi is. In teenstelling met die reaksieplan, was die afstand wat hierdie magte vanaf die kanaal ontplooi is, baie groot. Gevolglik was ' $n$ vinnige konsentrasie van pantsermagte om die kruising te stop nie moontlik nie (Sharon 1989: 294).

\section{Gevolgtrekkings}

Egipte se aanval op Israel in Oktober 1973 is 'n goeie voorbeeld op die gebied van vertolking, misleiding en verrassing. Egipte kon daarin slaag om morele verrassing te behaal, deurdat Israel totaal onverhoeds betrap is. Die verrassing is behaal in terme van tyd en metode. Die feit dat Egipte die aanval op 'n Joodse godsdienstige vakansiedag van stapel gestuur het, en die aanval om 14 h00 die middag plaasgevind het, was sentraal in die verkryging van die verrassing. Selfs nadat Israel oortuig is dat die aanval wel gaan plaasvind, was daar nog onsekerheid oor die presiese tyd daarvan. Israel is ook verras deur Egipte se gebruik van water om die grondfortifikasies te oorkom, sowel as sy gebruik van tenk- en lugafweerwapens om die Israeli tenk- en lugbedreiging te neutraliseer. 
Die suksesvolle verkryging van verrassing word verder toegeskryf aan die feit dat Egipte daarin kon slaag om te voorkom dat Israel konsentrasie van mag bewerkstellig deur vroegtydig te mobiliseer. In retrospek is dit duidelik dat Israel, weens Egipte se agterstand op militêre gebied, moes voorsien dat Egipte van verrassing gebruik sou maak indien hy Israel sou aanval.

Die Egiptiese aanval is 'n goeie voorbeeld van suksesvolle misleiding deur die verberging van vermoëns en voornemes vir die vyand. Israel was wel bewus van die kwantitatiewe verbeteringe in die Egiptiese weermag. Israel is steeds verras deur Egipte se besit en effektiewe gebruik van die nuutste lug- en tenkafweerwapens, asook Egipte se verberging van sy voorneme om aan te val. Die sukses van die verrassingsaanval kan aan Israel se swak vertolking van informasie toegeskryf word. Israel was nie in staat om Egipte se voorneme om aan te val, korrek te waardeer nie.

Goeie sekerheid aan die kant van Egipte en die suksesvolle gebruik van die dekstorie van 'n oefening deur sy gewapende magte naby die kanaal, het bygedra tot die skep van verrassing. Daar was egter geen gebrek aan informasie wat op ' $n$ aanval gedui het nie. Die vertolking van die informasie het die probleme geskep. Hierdie wanvertolking kan aan verskeie aspekte toegeskryf word. Die inligtingspersoneel se visie is beperk deur ' $n$ aantal vooropgestelde idees. Voorts was dit moeilik om te onderskei tussen korrekte, vals en misleidende informasie. Politici het die inligtingspersoneel indirek beïnvloed met hul idees.

Dit is duidelik dat inligting en die bedryf daarvan, van deurslaggewende belang is in die verhoudinge tussen state. Inligting kan vir enige staat, veral in krisistye,'n saak van oorlewing wees. Verrassing, misleiding en die vertolking van informasie is weens hul sentrale rol in die bedryf van inligting, van deurslaggewende belang.

Misleiding is ' $n$ uiters goeie metode om verrassing te bewerkstellig. Dit blyk dat daar 'n direkte verband is tussen die sukses en omvang van misleiding en die sukses en omvang van verrassing wat daaruit voortvloei. Sonder goeie sekerheid, beplanning en koördinering kan geen misleidingspoging suksesvol wees nie. Misleiding word makliker geskep deur bestaande vyandelike wanpersepsies en oortuigings te versterk as om te poog om nuwe wanopvattings te skep en te versterk. Die Egiptiese aanval op Israel het bewys dat voortdurende optrede wat nie tot oorlog lei nie, neig om die vyand te kondisioneer sodat hy sy gereedheid en waaksaamheid verslap.

Egipte het met sy aanval op Israel vootgegaan, ten spyte van sy swakkere militêre vermoëns. Dit is belangriker vir state om hul politieke oogmerke te bereik, as om militêre oorwinnings te behaal. Alhoewel dit belangrik is dat inligtingspersoneel 'n opponent se militêre vermoëns bepaal, wat relatief maklik is, is dit van groter belang om state se voornemens te bepaal. Veral militêre inligtingsorganisasies moet hulself nie beperk in die vertolking van hul informasie nie. Informasie moet geplaas word teen die breë agtergrond van 'n opponent se politieke, ekonomiese, sosio-maatskaplike en sielkundige omstandighede. Dit is veral belangrik om 'n staat se koste om oorlog te maak op te weeg teen sy omstandighede, sou hy nie tot oorlog oorgaan nie. 
Israel se wanvertolking van informasie beklemtoon die verhouding tussen die politieke oppergesag en inligtingsorganisasies van 'n land. Daar moet ' $n$ balans wees tussen die verskaffing van politieke leiding deur politici en die onafhanklike funksionering van inligtingsorganisasies om die kreatiwiteit van personeel te verseker. Die uitdaging is dat politici die inligtingspersoneel moet rig in hul werksaamhede sonder dat die inligtingspersoneel se objektiwiteit in die vertolking van informasie deur politici beïnvloed word. Inligtingspersoneel moet weer op hulle beurt die inligting aan die besluitnemers oordra op só 'n wyse dat hulle nie die besluitnemers se objektiwiteit in die neem van besluite, beïnvloed nie. Inligtingspersoneel moet nie besluitnemers in 'n bepaalde rigting "druk" of besluite namens hulle neem nie.

Dit is duidelik dat menslike persepsies, vooroordele en opvattings 'n belangrike rol speel in die vertolking van informasie. Informasie is feite wat alleen geen waarde het nie. Hierdie feite moet deur vertolking teen die regte agtergrond geplaas word om interpretasie daarvan moontlik te maak. Solank as wat die mens met sy oortuigings betrokke is by die vertolking van feite, sal daar altyd 'n moontlikheid bestaan dat misleiding en verrassing kan plaasvind. Die uitdaging is nie net om tussen korrekte en vals informasie ("noise and signals") te onderskei nie, maar om die feite teen die regte agtergrond te plaas, sodat die korrekte afleidings gemaak kan word. 


\section{BIBLIOGRAFIE}

Betts, R.K. 1982. Surprise Attack: Lessons for Defense Planning. Washington: The Brookings Institution.

Brodin, K. 1978. Surprise Attack: The Case of Sweden, in Journal of Strategic Studies, May.

Clausewitz, C. 1984. On War. Edited and Translated by Howard, M. \& Paret, P. Princeton: Princeton U.P.

Cohen, E.A. \& Gooch, J. 1990. Military Misfortunes: The Anatomy of Failure in War. New York: The Free Press.

Daniel, D.C. \& Herbig, K.L. 1982. Propositions on Military Deception. (In Gooch, J. \& Perlmutter, A. (eds.), Military Deception and Strategic Surprise.) London: Frank Cass.

Dupuy, T.N. 1982. '73 War. The Arab-Israeli Conflict: A Military Analysis. Strategy \& Tactics. Nr 90. Jan/Feb

Handel, M.I. 1982. Intelligence and Deception. (In Gooch, J. \& Perlmutter, A. (eds.), Military Deception and Strategic Surprise.) London: Frank Cass.

Handel, M.I. 1984. Intelligence and the Problem of Strategic Surprise, in Journal of Strategic Studies, 7 (no. 3).

Hanzhang, T. 1993. Sun Tzu: The Art of War. Hertfordshire: Wordsworth Editions.

Herzog, C. 1984. The Arab-Israeli Wars: War and Peace in the Middle East. New York: Vintage Books.

Hybel, A.R. 1986. The Logic of Surprise in International Conflict. Lexington: Lexington Books.

Kennedy, W.V. (ed.). 1983. The Intelligence War. London: Leisure Hour.

Knorr, K. 1979. Strategic Intelligence: Problems and Remedies. (In Laurens, M., Strategic Thought in the Nuclear Age.) London: Heineman.

Knorr, K. 1983. On Strategic Surprise Surprise. (In Brodie, B., Intriligator, M.D. \& Kolkowicz, R. (eds.), National Security and International Stability.) Cambridge: Oelgeschlager, Gunn and Hain. 
Liddell Hart, B.H. 1974. Strategy. New York: Signet.

Militêre Woordeboek $(M W)$ SA Weermag. Datum van Publikasie Onbekend. Publikasie deur SAW Afdeling Personeel: Direkteur Taaldiens. Pretoria.

Naveh, S. 1997. In Pursuit of Militay Excellence: The Evolution of the Operational Theory. London: Frank Cass.

Sharon, A \& Chanoff. 1989. Warrior: The Autobiography of Ariel Sharon. London: Macdonald

Shlaim, A. 1976. Failures in National Intelligence Estimates: The Case of the Yom Kippur War, in World Politics, XXVIII (no. 3).

Simpkin, R.E. 1994. Race to the Swift: Thoughts on Twenty-First Century War. London: Brassey's

Stein, J.G. 1982. Military Deception, Strategic Surprise, and Conventional Deterrence: A Political Analysis of Egypt and Israel, 1971-73. (In Gooch, J. \& Perlmutter, A. (eds.). Military Deception and Strategic Surprise.) London: Frank Cass. 